\title{
Perancangan Sistem Informasi Pemerintahan Berbasis Web Studi Kasus Kantor Kelurahan Sumur Batu
}

\author{
Yusriel Arief Ferdiyanto \\ Universitas Bina Sarana Informatika \\ e-mail: yusriel.yaf@bsi.ac.id
}

Cara Sitasi: Ferdiyanto, Y. A. (2019, Maret). Perancangan Sistem Informasi Pemerintahan Berbasis Web Studi Kasus Kantor Kelurahan Sumur Batu. (S. Dalis, Ed.) Paradigma - Jurnal Komputer dan Informatika, 21(1), 113116. doi:10.31294/p.v21i1.5268

\begin{abstract}
Nowadays, in globalization era information technology is advancing rapidly. Computers are equipment that was created to facilitate human work, currently achieving progress both in hardware and software. Kelurahan Sumur Batu requires an information system that supports and provides information services that are satisfying for information seekers. Kelurahan Sumur Batu is one of the smallest units of the DKI Jakarta Government which has an important role in conveying the vision and mission of the DKI Jakarta Government. The design of information systems is the best solution to solve the problem of lack of information for the people in Kelurahan Sumur Batu. With the existence of a web-based Government Information System, the information obtained will become more attractive, faster and easily accessible to many people.
\end{abstract}

Keywords: Information Systems, Government Information System

\section{PENDAHULUAN}

Setiap orang membutuhkan informasi untuk menunjang aktivitas mereka, sehingga berusaha untuk mengakses informasi secepat mungkin (Fitriani, 2017). Perkembangan teknologi informasi diseluruh dunia telah membuat hidup manusia menjadi semakin mudah. Terutama sejak diciptakannya jaringan internet, komunikasi menjadi semakin tidak terbatas dan tanpa hambatan, baik hambatan geografis maupun hambatan waktu (Christian \& Ariani, 2018).

Website merupakan salah satu contoh berkembangnya teknologi di bidang informasi yang berbasis internet. Informasi yang diberikan melalui internet ini akan sangat membantu penggunanya dalam memenuhi suatu hajat kebutuhan yang ingin diperoleh dengan mudah tanpa harus bersusah payah mencari informasi kesana kemari (Wasiyanti \& Talaohu, 2016).

Sesuai dengan program pemerintah DKI Jakarta untuk menuju pemerintahan good governance maka diperlukan sebuah sarana informasi yang dapat diakses dengan mudah oleh seluruh lapisan masyarakat yang memerlukan informasi di suatu wilayah tertentu di DKI Jakarta. Pada saat ini kelurahan Sumur Batu sebagai salah satu unit atau satuan kerja pada perangkat daerah (SKPD) yang melayani masyarakat di wilayah Kelurahan Sumur Batu memerlukan sebuah sarana informasi yang dapat dengan mudah di akses oleh warga atau yang berkepentingan.
Dari masalah tersebut penulis berpendapat bahwa penggunaan internet atau website dapat membantu Kelurahan Sumur Batu memberikan informasi kepada warga Kelurahan Sumur Batu atau yang berkepentingan dalam rangka pelaksanaan pelayanan kepada warga masyarakat di wilayah Kelurahan Sumur Batu pada khususnya dan DKI Jakarta pada umumnya. Atas alasan tersebut maka penulis mengambil judul yaitu: "Perancangan Sistem Informasi Pemerintahan Berbasis Web Studi Kasus Kantor Kelurahan Sumur Batu”.

\section{Sistem Informasi}

Menurut (Sintawati \& Sari, 2017), Sistem Informasi merupakan kesatuan elemen-elemen yang saling berinteraksi secara sistematis dan teratur untuk menciptakan dan membentuk aliran informasi yang akan mendukung pembuatan keputusan dan melakukan kontrol terhadap jalannya perusahaan.

\section{Website}

Menurut (Adelheid, 2014) "Website adalah halaman informasi yang disediakan melalui jalur internet sehingga bisa diakses dimanapun selama terkoneksi dengan jaringan internet. Website merupakan komponen atau kumpulan komponen yang terdiri dari teks, gambar, suara, animasi sehingga lebih merupakan media informasi yang menarik untuk dikunjungi".

PHP (Page Hypertext Preprocessor)

Menurut (Sintawati \& Sari, 2017) "PHP yang merupakan singkatan dari Page Hypertext 
Preprocessor merupakan bahasa skrip yang tertanam dalam HTML untuk eksekusi bersifat server side".

MySQL

"MySQL adalah suatu RDBMS (Relational Database Management System) yaitu aplikasi sistem yang menjalankan fungsi pengolahan data”. (Sibero, 2013)

MySQL berfungsi untuk mengolah database menggunakan bahasa SQL. MySQL bersifat open source sehingga kita bisa menggunakannya secara gratis. Pemrograman PHP juga sangat mendukung dengan database MySQL.

\section{ERD (Entity Relationship Diagram)}

Menurut (Fathansyah, 2012) "ERD merupakan model yang berisi komponen-komponen himpunan entitas dan himpunan relasi yang masing-masing dilengkapi dengan atribut-atribut yang merepresentasikan seluruh fakta dari 'dunia nyata' yang kita tinjau".

ERD merupakan suatu model untuk menjelaskan hubungan antar data dalam basis data berdasarkan objek-objek dasar data yang mempunyai hubungan atau relasi ERD untuk memodelkan struktur data dan hubungan antar data, untuk menggambarkannya digunakan beberapa notasi dan simbol.

\section{Pengujian Web}

Menurut (Pressman, 2012) "Black Box Testing atau pengujian Kotak Hitam atau juga disebut Behavioural Testing berfokus pada persyaratan fungsional dari perangkat lunak. Artinya teknik black box testing memungkinkan untuk mendapatkan set kondisi masukan yang sepenuhnya akan melaksanakan semua persyaratan fungsional untuk suatu program".

\section{METODOLOGI PENELITIAN}

Dalam penelitian ini metode pengumpulan data yang penulis lakukan adalah:

a. Observasi

Teknik pengumpulan data dan informasi dengan cara mengamati langsung untuk mendapatkan berbagai keterangan tentang pelayanan masyarakat di Kelurahan Sumur Batu serta berbagai data lain yang berguna bagi pembuatan website.

b. Wawancara

Dalam hal ini penulis melakukan wawancara dengan narasumber sekretaris Kelurahan Sumur Batu dengan menggunakan daftar tanya jawab yang terstruktur.

c. Studi Pustaka

Studi ini dilakukan dengan cara mempelajari dan meneliti berbagai literatur yang bersumber dari buku-buku, artikel ataupun jurnal penelitian sejenis yang pernah dilakukan sebelumnya.

Sedangkan metode pengembangan perangkat lunak ini menggunakan model waterfall (Sommerville,
2007) yang terbagi menjadi tiga tahapan, yaitu:

a. Analisis Kebutuhan

Tahapan ini sangat menekan pada masalah pengumpulan kebutuhan pengguna pada tingkatan sistem dengan menentukan konsep sistem beserta antarmuka yang menghubungkannya dengan lingkungan sekitar. Hasilnya berupa spesifikasi system.

b. Perancangan Sistem dan Perangkat Lunak

Proses perancangan sistem ini difokuskan pada empat atribut, yaitu struktur data, representasi antarmuka, arsitektur perangkat lunak dan interaksi antar objek didalam kelas.

c. Implementasi

Pada tahap ini, perancangan perangkat lunak direalisasikan sebagai serangkaian program atau unit program.

\section{HASIL DAN PEMBAHASAN}

Analisa Kebutuhan

1. Kebutuhan User (Pengunjung)

User (Pengunjung) dapat melihat informasiinformasi yang ditampilkan pada website.

2. Kebutuhan Admin (Pemilik Website)

Admin dapat melakukan update pada website dalam menambahkan informasi-informasi terbaru

\section{Perancangan Antar Muka}

1. Rancangan Desain Login Admin

\begin{tabular}{|c|}
\hline Marquee selamat datang \\
\hline \begin{tabular}{c|}
\hline Logo \\
DKI
\end{tabular} \\
\hline Username \\
\hline Password \\
\hline
\end{tabular}

Gambar 1. Rancangan Desain Login Admin

Merupakan halaman index yaitu halaman pertama kali diakses oleh admin website. Halaman ini merupakan halaman untuk mengakses beranda admin. Admin diharuskan melakukan penginputan username dan password untuk dapat masuk kedalam beranda admin

\section{Rancangan Desain Beranda Admin}

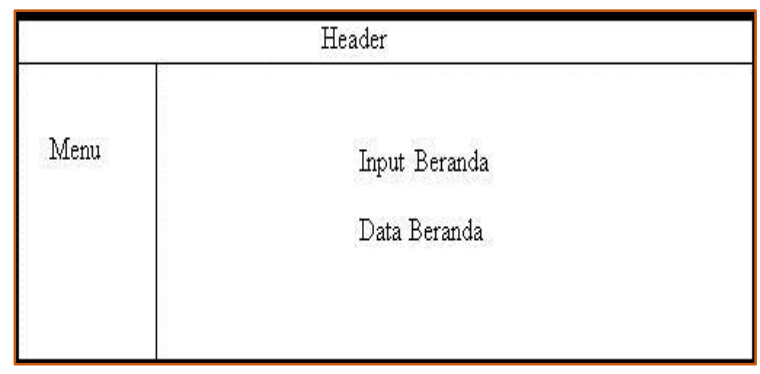




\section{Gambar 2. Rancangan Desain Beranda Admin}

Merupakan halaman untuk menginput artikel singkat dan link artikel tersebut pada halaman beranda. Pada Halaman ini juga terdapat menu-menu lainnya untuk mengubah tampilan pada halaman-halaman lainnya.

\section{ERD (Entity Relationship Diagram)}

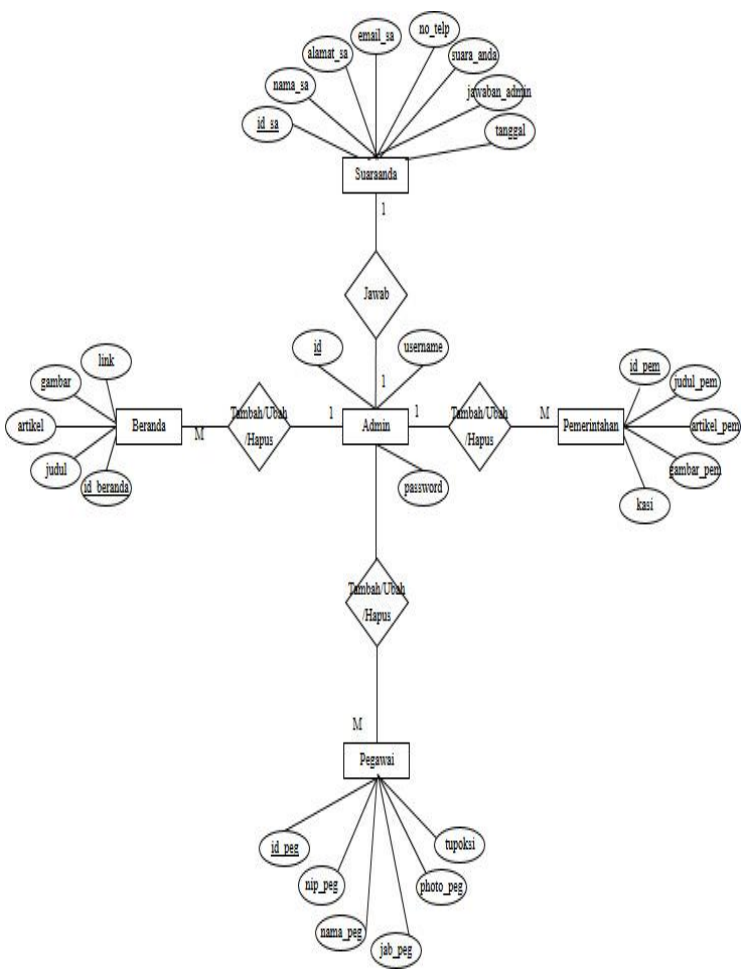

Gambar 3. ERD

\section{Struktur Navigasi}

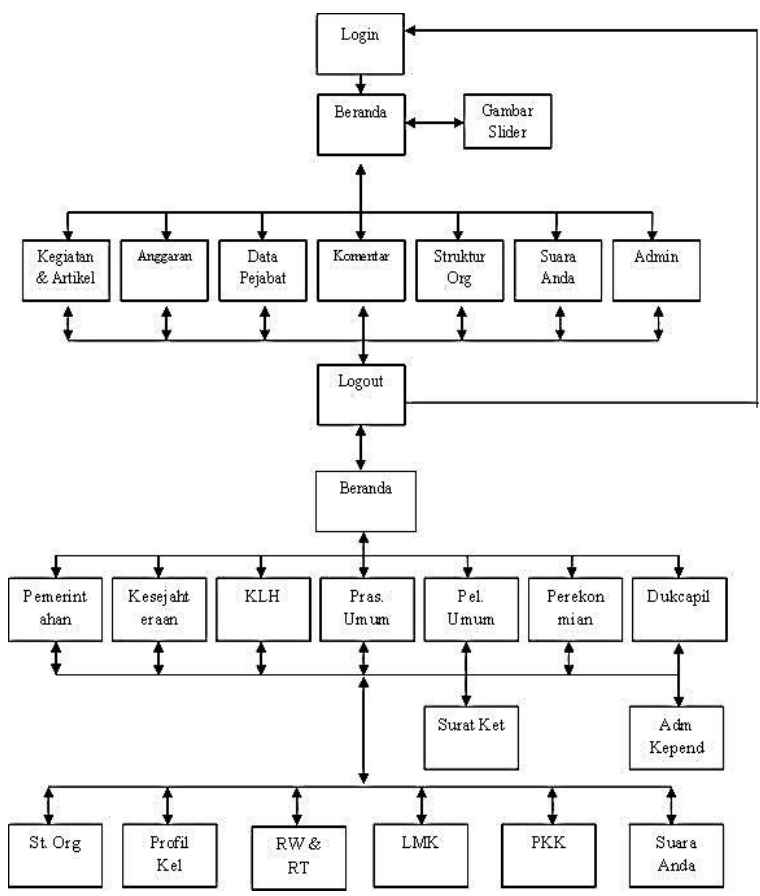

\section{Gambar 4. Struktur Navigasi \\ Implementasi \\ 1. Halaman Login Admin}

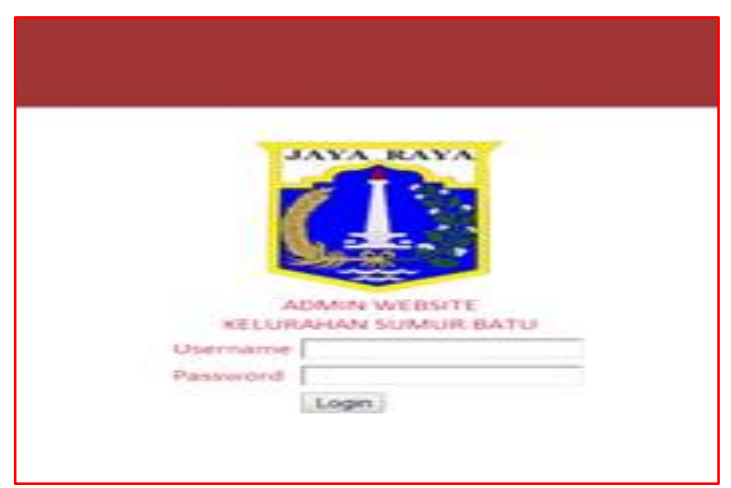

Gambar 5. Login Admin

Proses Program: setelah mengakses halaman admin, user dapat memasukkan username dan password yang sesuai/yang telah teregistrasi untuk masuk kedalam beranda admin.

\section{Halaman Beranda Admin}

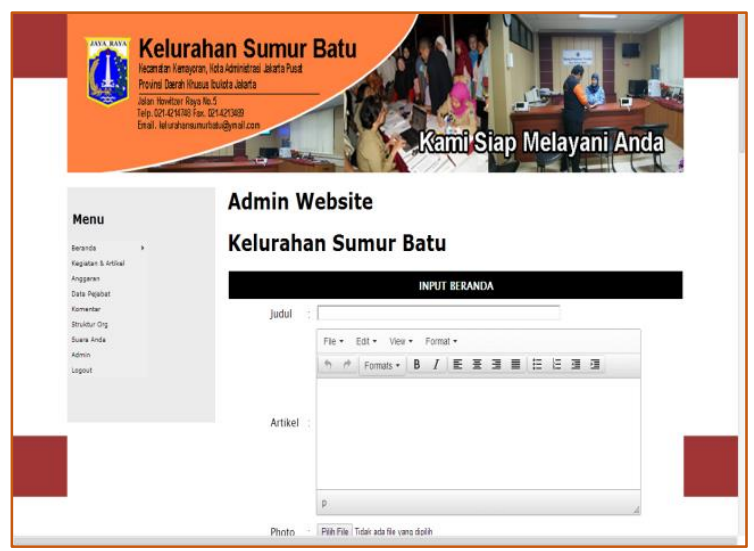

Gambar 6. Halaman Beranda Admin

Proses Program: setelah memasukkan username dan password yang sesuai maka user akan masuk kedalam beranda admin untuk melakukan penginputan, pengeditan dan penghapusan berita atau gambar pada halaman beranda.

\section{Halaman Beranda Pengunjung}

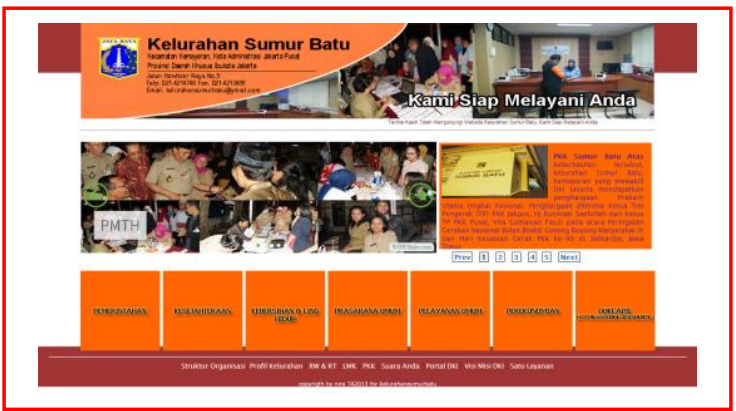

Gambar 7. Halaman Beranda Pengunjung Proses Program: halaman akan muncul ketika pengunjung mengakses alamat website. 


\section{Halaman Pemerintahan}

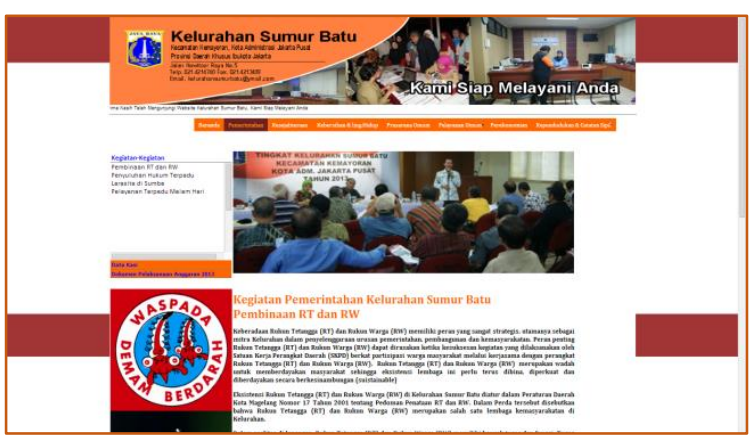

Gambar 8. Halaman Pemerintahan

\section{Pengujian Unit}

Pengujian terhadap program yang dibuat menggunakan blackbox testing yang fokus terhadap proses masukan dan keluaran program

\begin{tabular}{|c|c|c|c|c|c|}
\hline No & $\begin{array}{c}\text { Skenario } \\
\text { Pengujian }\end{array}$ & Test Case & $\begin{array}{l}\text { Hasil yang } \\
\text { diharapkan }\end{array}$ & $\begin{array}{c}\text { Hasil } \\
\text { Pengujian }\end{array}$ & Kesimpulan \\
\hline 1 & $\begin{array}{l}\text { Username dan } \\
\text { Password tidak } \\
\text { diisi kemudian klik } \\
\text { tombol login }\end{array}$ & $\begin{array}{c}\text { Username: } \\
\text { (Kosong) } \\
\text { Password: } \\
\text { (Kosong) }\end{array}$ & $\begin{array}{l}\text { Sistem akan } \\
\text { menolak akses user } \\
\text { dan menampilkan } \\
\text { "Username harus } \\
\text { diisi" }\end{array}$ & $\begin{array}{l}\text { Sesuai } \\
\text { harapan }\end{array}$ & Valid \\
\hline 2 & $\begin{array}{l}\text { Mengetikkan } \\
\text { Username dan } \\
\text { Password tidak } \\
\text { diisi atau kosong } \\
\text { kemudian klik } \\
\text { tombol login }\end{array}$ & $\begin{array}{l}\text { Username: Admin } \\
\text { Password: } \\
\text { (Kosong) }\end{array}$ & $\begin{array}{l}\text { Sistem akan } \\
\text { menolak akses user } \\
\text { dan menampilkan } \\
\text { "Password harus } \\
\text { diisi" }\end{array}$ & $\begin{array}{l}\text { Sesuai } \\
\text { harapan }\end{array}$ & Valid \\
\hline 3 & $\begin{array}{c}\text { Username tidak } \\
\text { diisi dan Password } \\
\text { diisi kemudian klik } \\
\text { tombol login }\end{array}$ & $\begin{array}{c}\text { Username: } \\
\text { (Kosong) } \\
\text { Password: rahasia } \\
\text { (benar) }\end{array}$ & $\begin{array}{c}\text { Sistem akan } \\
\text { menolak akses user } \\
\text { dan menampilkan } \\
\text { "Username harus } \\
\text { diisi" }\end{array}$ & $\begin{array}{l}\text { Sesuai } \\
\text { harapan }\end{array}$ & Valid \\
\hline
\end{tabular}

\section{Gambar 9. Hasil Pengujian Black Box Testing} Halaman Login Admin

\section{KESIMPULAN}

Sebuah web sederhana yang penulis susun ini merupakan web dinamis sederhana tetapi memiliki arti penting dalam memberikan informasi kepada masyarakat dan mengembangkan peran serta masyarakat dalam pembangunan khususnya di Kelurahan Sumur Batu. Penyusunan website dengan sarana software yang telah mudah didapat sangat membantu penulis dalam mendesain tampilan website yang menarik dan menampilkan data-data yang ingin diinformasikan atau diberikan kepada masyarakat yang dapat diakses melalui internet. Dengan adanya website ini diharapkan Kelurahan Sumur Batu dapat meningkatkan kinerja para aparaturnya guna tercapainya good governance di Pemerintah Provinsi DKI Jakarta pada umumnya.

\section{REFERENSI}

Adelheid, A. (2014). Website No. 1 Cara Mudah Bikin Website dan Promosi ke SEO. Medan: Mediakom.

Christian, A., \& Ariani, F. (2018). Rancang Bangun Sistem Informasi Peminjaman Perangkat Demi Video Conference Berbasis Web Dengan Metode Waterfall. Jurnal Pilar Nusa Mandiri, 14(1), 131-136.

Fathansyah. (2012). Basis Data Edisi Revisi. Bandung: Informatika.

Fitriani, Y. (2017). Analisis Pemanfaatan Berbagai Media Sosial Sebagai Sarana Penyebaran Informasi Bagi Masyarakat. Jurnal Paradigma, 19(2), 148-152.

Nilawati, L. (2018). Analisa Model Rapid Application Development Untuk Rancang Bangun Sistem Informasi Penyewaan Apartemen. Jurnal Paradigma, 20(2), 1926.

Pressman, R. S. (2012). Rekayasa Perangkat Lunak Pendekatan Praktisi (Buku 1). Yogyakarta: Andi.

Sari, A. M. (2017). Aplikasi Situs Web Penjualan Hijab Online. Paradigma, 19(2), 113-117.

Sibero, A. F. (2013). Web Programmer Power Pack. Yogyakarta: Mediakom.

Sintawati, I. D., \& Sari, A. M. (2017). Perancangan Sistem Informasi Penjualan Perlengkapan Tidur Berbasis Web Studi Kasus Toko Batik Galinah Jakarta. Jurnal Paradigma, 19(2), 127-130.

Sommerville, I. (2007). Software Engineering 8th Edition. England: Person Education Limited.

Wasiyanti, S., \& Talaohu, R. (2016). Sistem Informasi Penjualan Obat Berbasis Web Pada Apotek Kondang Waras Depok. Jurnal Paradigma, 18(2), 49-62.

\section{PROFIL PENULIS}

Yusriel Arief Ferdiyanto, ST, MMSi. Jakarta 29 Juli 1977. Lulus dari Program Strata Satu (S1) Program Studi Teknik Informatika Universitas Gunadarma Tahun 1999. Lulus dari Program Strata Dua (S2) Program Studi Manajemen Sistem Informasi Jakarta Tahun 2003. Aktif sebagai Dosen Tetap Pada Universitas Bina Sarana Informatika. 